\title{
The Use of Cinematherapy Techniques in Developing Religious Tolerance in Students with Multicultural Education Insights
}

\author{
Charles $^{1}$, Intan Sari $^{2}$, Merry Prima Dewi ${ }^{3}$, Arjoni ${ }^{4}$, Supratman Zakir ${ }^{5}$ \\ $1,2,3,4,5$ Faculty of Educatioan and Teaching, Institut Agama Islam Negeri (IAIN) Bukittinggi \\ *supratman@iainbukittinggi.ac.id
}

\begin{abstract}
The purpose of this article is to describe the development of religious tolerance of students through group counseling activities with cinema therapy techniques with multicultural education insight (experimental studies at Xaverius Bukittinggi High School). This study uses a quantitative approach with quasi experimental designs pretest and posttests. The population of this research was the tenth grade students of Xaverius Bukittinggi High School Xaverius and the sampling technique used was purposive sampling. The steps in this research were; conducting preliminary studies, literature studies, collecting data, analyzing data (by using normality test, homogeneity test and t test) and making conclusions. The results of this study proves that the development of religious tolerance for the students' of SMA Xaverius Bukittinggi in general is considered in good categories. After the experiments have been proven; there is a significant difference in the religious tolerance of experimental group students before and after group counseling activities with multicultural education-oriented cinema therapy techniques, there is no difference in the religious tolerance of control group students before and after group counseling activities without using cinema therapy techniques with multicultural education-oriented techniques, and there are significant differences in tolerance religious students in the experimental group with the control group after group counseling with cinema therapy techniques with multicultural education insight. From the results of this study it was proved that the development of student religious tolerance through group counseling activities was effective by using cinema therapy techniques. The results of this study can be used as consideration for developing a counselling program for the development of religious tolerance in high schools.
\end{abstract}

Keywords: Cinema Therapy; Tolerance; Multicultural; Religious

\section{Introduction}

Religious tolerance is a form of embodiment of multicultural life that is harmonious in areas of population that have a variety of religions, cultures and streams of belief. Religious tolerance fosters mutual understanding and respect for differences in faith and worship which become an entry point for the realization of an atmosphere of dialogue and harmony among religious believers in social life. Efforts to avoid conflicts between religious believers should become a collective awareness of all groups of people, from children, adolescents, adults, to parents, both students, students, employees, bureaucrats, and other communities.[1] Tolerance 
is a fundamental virtue in democratic life, but it has ambivalent power which is manifested in two forms, namely a solid form and a democratic form.[2]

Religious tolerance is an awareness of addressing and behaving in an open, independent, respectful and positive social interaction towards interfaith individuals who believe and worship according to their religion and or beliefs, so that a harmonious life is achieved, peace and harmony in society, nation and religion. Indicators of religious tolerance, namely attitudes and behavior; a). Open (understanding, accepting and maintaining the reality of the different concepts of faith and worship of each religion and stream of beliefs), b). Freedom in practicing the faith and worship of each religion and flow of beliefs, c). Respect the concept of the development of faith and religious worship and the flow of beliefs and d). Positive interaction and communication of each religion and stream of beliefs. Factors that influence the development of religious tolerance can be seen from internal factors (knowledge, interests, attitudes, skills and experience) and externally influenced by the community and mass media environment.[3]

Until now, Indonesia has been reported by religious research centers and human rights protection organizations as a state that still does not guarantee the protection of human rights, especially in religious freedom. The 2013 Human Rights Watch report in 2012 it was found 264 cases of violence against religious minority groups and in 2013 increased becoming 243 cases. Another report, namely the report on freedom of religion and belief published by The Wahid Institute in 2013 stated that in 2013 there were still 106 acts of religious intolerance.[3]

From some of the results of the above studies recommending religious tolerance in the community, especially in the educational environment is needed.[4] He also mentions students as the hope of the nation's future in carrying out the mandate of leadership and social change agents, presumably must be equipped with sufficient knowledge, experience and wisdom in responding to the nation's plurality which is indeed very high. For this reason, religious tolerance research is very important among students. Besides university students, students at school also need attention. This is reinforced from the recommendations of research results Ummi Murzanah conveying the attitude of intolerance has spread to students, therefore further research is needed among students.

Based on the law No. 20 of 2003 concerning the National Education System implicitly regulates religious tolerance education, namely education that is carried out democratically and fairly and is not discriminatory by upholding human rights, religious values, cultural values, and national pluralism.

Violations of education that are democratic and tolerant, there are three basic requirements that must be met. First, the practice of education always emphasizes the principle of justice so that all students get a fair and equal education. Second, the learning process is kept away from the nature of bias and stereotypes. Third, the learning process ends on developing students' awareness of themselves, respecting other cultures outside of themselves, and being able to work together amidst existing cultural differences. [5]

Manifestation of the growth in understanding and attitude of religious tolerance as recommended by the above research results is certainly needed as a guidance and coaching from Educators, especially educators who are in schools where students in the school are multi-religious and / or multi-religious. Educators in schools can collaborate, including cooperation between counseling teachers and Islamic religion teachers and other teachers with a variety of strategies, methods, media, and materials that contain multicultural education that teaches tolerance in living side by side. Amongst the possible strategies are able to realize this through group counseling activities. 
Group counseling activities are part of the responsive services of Guidance and Counseling. Achmad Juntika stated; "Group counseling is an activity of assistance to individuals carried out in group situations. Group counseling can be in the form of delivery of information or group activities discussing educational, work, personal and social issues".[6] Prayinto stated; "Group counseling is carried out to enable group dynamics aimed specifically at discussing certain topics that contain actual (warm) problems and are of concern to group participants, thus encouraging the development of feelings, thoughts, perceptions, and insights, attitudes that support the realization of more effective and effective behavior. Discussion of topics in group counseling can use various techniques and approaches. The technique and approach aims to provide assistance to group members who face relatively similar problems so that they can identify, understand and solve their problems and can make appropriate adjustments to the group problems they experience together.[7] The focus of the topic on effective group counseling activities was developed to increase religious tolerance in schools with cinema therapy techniques.[8]

Cinema therapy is a method of brief assistance, dynamic training because it facilitates quickly between personal and therapeutic understanding between counselor and client. Dermer and Hutchings define the cinema therapy process of using film as intervene and describe it as an indirect approach process, which can be applied to deal with various problems. The problems in question include the problem of low religious tolerance of students.[9]

Tyson, Foster, and Jones define cinema therapy as a therapeutic approach that prepares clients to watch and assess films based on the character's interactions with others, their environment and personal problems, by developing links to resolve positive therapeutics.[10] Cinema therapy uses content experiences for processing and characters in films to help clients change negative beliefs, manage destructive emotions, increase insight, develop themselves, and rediscover strength.[9] Moreover, Sharp, Smith, \& Cole explain cinema therapy as a therapeutic technique that involves careful selection and assignment of films so clients watch with follow-up processing of their experiences during therapy sessions.[11] Films serve to educate clients, normalize and reframing problems, and broadening ideas. [9]

From the explanation above it can be understood, cinema therapy is a therapeutic method that functions to change the behavior, attitudes, ways of thinking of individuals and groups towards a positive and effective development of competence through cinema film screening media.

The selection of films that fit the theme needs to be considered and selected so that the film touches the client's understanding. Dermer and Hutchings stated that films must be chosen based on the client's problem, goals, strengths, ability to understand film, character similarity, and diversity issues.[9] Then, Marsick proposes that films should be chosen based on: a) effective characters, b) content that matches the problem, c) the client enjoys the film, d) characters that solve the problem, e) indirect messages, and f) the spirit or inspiration of the theme.[12]

Cinema therapy stages according to Dermer and Hutchings is The Assessment Stage is the stage of finding a film that suits its purpose, the Implementation Stage which is preparing an appropriate film footage and preparing a rational reason for watching a film, the Debriefing Stage which is the stage of discussing thoughts and feelings in a film that is beneficial to students.[9]

From the elaboration of the theory above, it is necessary to implement it in order to increase students' religious tolerance so that they have effective understanding, knowledge, insight and religious skills in carrying out their daily lives. Besides this, the increase in students' religious tolerance also functions as a preventive occurrence of daily religious 
intolerance in social life. The selection of films that will be presented in this cinema therapy technique is a multicultural charged film.

Multicultural education is education that offers students about perspectives and attitudes in dealing with differences and heterogeneity of ethnic groups, gender relations, relations between religions, interest groups, culture and subcultural, as well as other forms of diversity. "Multicultural education is expected to actively prepare students as citizens who are ethnically, culturally and religiously diverse, to become human beings who value diversity, be proud of themselves, the environment and multiple realities.[13]

The implementation of the explanatory theory concept above is certainly good to be done especially in schools that have students with varied cultural and religious backgrounds, such as the SMA XAVERIUS Bukittinggi. SMA XAVERIUS Bukittinggi founded by a foundation with a minority religious background in the city of Bukittinggi but has students of various ethnic and religious backgrounds. From the results of preliminary field studies conducted by researchers in August 2018 at the School through observations and interviews with these teachers and students, the following problems were found: There are students from different ethnics, minangnese, Javanese, Bataknese, Chinese and have a background in Islam, Catholicism, Protestantism, Buddhism. There are indications that the inter-religious interaction between students has not yet developed integratively in their activities. There are indications that minority students feel reluctant to associate with the majority religious group and vice versa. Strategies and / or methods, materials, media for fostering religious tolerance are minimal and inclusive inclination.

Research report by Dwi Winanto Hadi, et al from the data and Statistics Center for Education and Culture revealed; "The results of the study of tolerance in Indonesia and its factors based on the 2014 National Socio-Economic data show that tolerance towards activities carried out by other religions in Indonesia tends to be low, while the factors affecting tolerance in households in Indonesia are education level, economic status, classifications of residence, job status, gender and age.'[14] Furthermore, Rina Hermawati in her study of religious tolerance in the city of Bandung revealed; "The issue of religion is still a strong factor to trigger in-group and out-group identity-based sentiments, so they are prone to triggering conflict ".[15] Next, Toto Sunarya, in his journal revealed; "Religious tolerance is an actual problem of all time. Actualization of religious tolerance in Indonesia is considered far from ideal, therefore socialization and coaching need to be improved "..[4]

Finally, Casram, in his research results revealed; "Ideal religious tolerance should be built through the active participation of all members of diverse religious communities in order to achieve the same goals on the basis of togetherness, inclusive attitudes, respect and mutual understanding regarding the implementation of rituals and certain doctrines of each religion.[16]

\section{Methodology}

This research approach is quantitative with the type of experimental research. This study aims to determine the effect of a treatment that is group counseling activities with cinema therapy techniques with multicultural education insight to predict or predict the development of religious tolerance of SMA Xaverius students in the experimental and control groups. This research design is quasi experiment or quasi-experimental, which is an experimental design that allows researchers to control as many variables as possible from the situation. 
Experimental design conducted with pre-test (before treatment is given) and post-test (after treatment in group counseling activities with cinema therapy techniques with multicultural education insight) is given, to the experimental group while the control group is still carried out group counseling but without the use of educational-oriented cinema therapy techniques multicultural. The steps of this research are preliminary studies, literature studies, data collection, and data analysis and research conclusions. The design of this study can be described as follows:

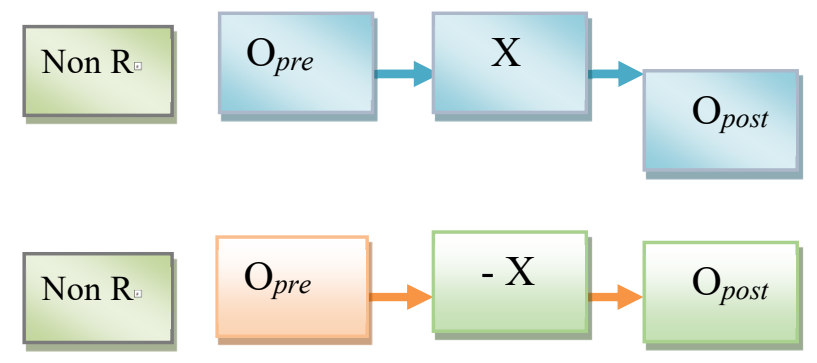

Figure 1. Design of Research

where :

Non R : Non Randomization

Opre : Pre-test

Opost : Post-test

$\mathrm{X} \quad$ : Treatment

- X : No Treatment

The object of this research was the students of SMA Xaverius Bukittinggi. The reason the researcher chose the object of the study was due to the discovery of interesting phenomena of religious tolerance, namely the diversity of students' religious, ethnic and cultural backgrounds. These conditions require the development of constructive religious tolerance so that the realization of harmony in life between religions and cultures of SMA Xaverius Bukittinggi students. In addition, it is noted from the material and development strategy equipment, the school is still limited and requires an effective varied model or strategy to develop the religious tolerance of students in the school.

For the sampling, there are several steps that researchers did, including the following: 1) Selecting schools to be used as research samples. 2) Selecting the level of the research sample class, 3). Carry out the pre test., 4) Chose a sample as an experimental group and a control group. The sample of this research was class XII, since class XII have experienced situations and processes of socialization and interaction that are sufficient and rich in experience compared to class XI and X. Furthermore, after determining the class the researchers pay attention to the local and what majors have varying degrees of diversity. After observing and analyzing the data, it was found that class XII IPS 1 had students who varied from other religions, ethnicities and cultures. Furthermore, after finding groups of students who have a diversity of religions and cultures, researchers conducted a questionnaire to determine the level of tolerance for each student. Furthermore, the results of the questionnaire were analyzed and carried out identification and grouped into experimental and control groups, so that 12 people were found experimental group and 12 control groups. 
After the research sample was determined, the researchers then developed the research instrument.The instrument of religious tolerance used in this study uses the religious tolerance scale questionnaire. The main theory of religious tolerance is transpersonal psychology. Transpersonal psychology views humans as creatures of God who are always attached to religious values which are believed to be behaviors in life activities. Peace and happiness can be obtained through behavior that constantly interacts with God and the universe. Compassion between humans and nature will make life more meaningful and peaceful. From this philosophical foundation, the writer examines other theories related to religious tolerance and ultimately determines the various theories which form the concept of religious tolerance. The lattices of this instrument can be seen as follows:

Table 1. Indicator of Instrument

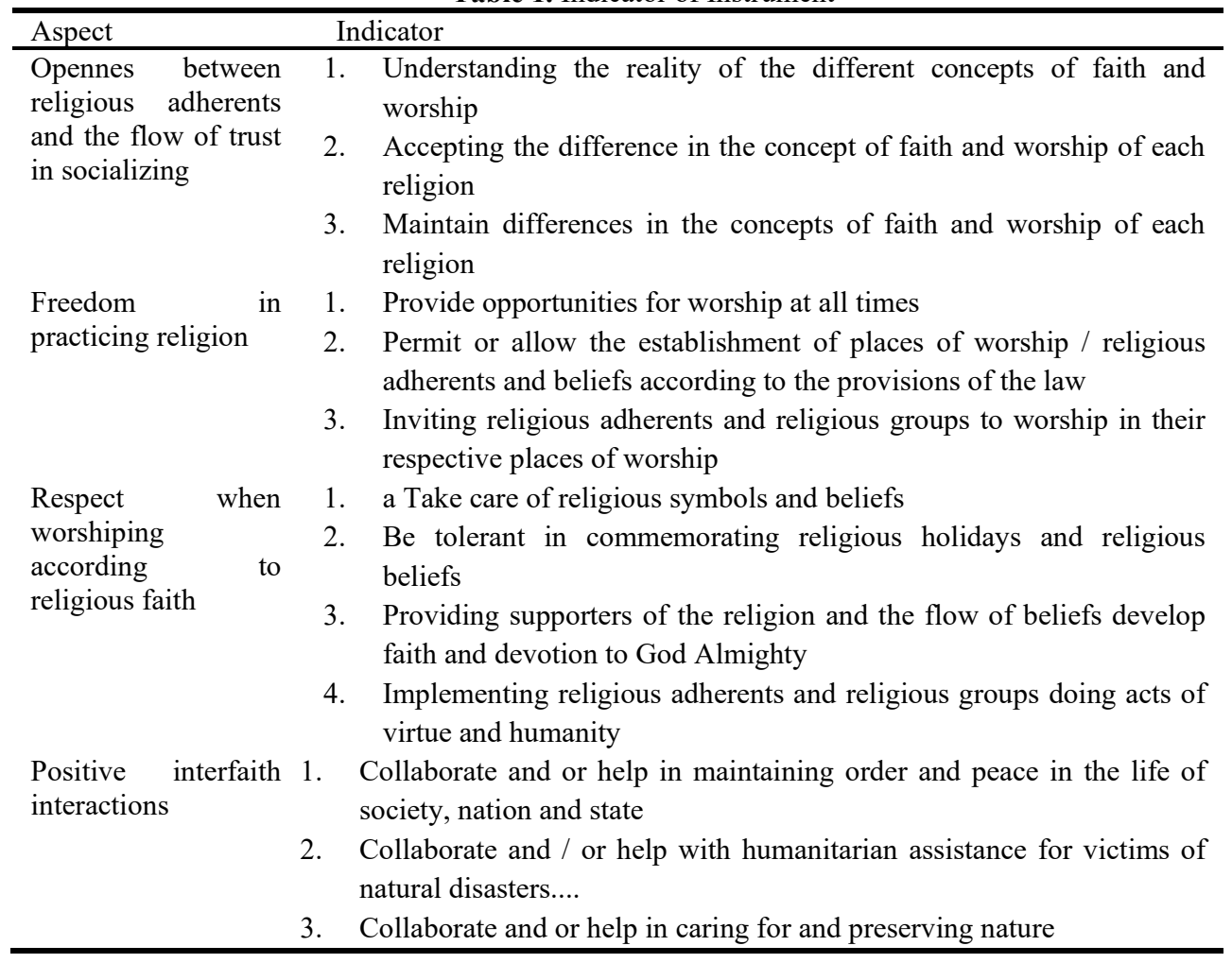

After the questionnaire is arranged, the researcher conducts a theoretical validation (judgment) to the expert team. This theoretical validity test considers construct validity and content validity. As for the questionnaire expert team, Dr. Mudjiran, M.Sc., Kons. as a guidance and counseling instrumentation expert, Dr. Nunu Burhanuddin, Lc, MA, and Dr. Wedra Aprison, M.Ag., as religious tolerance instrumentation expert. After the instrument got the results of judgment and has been improved, the second stage, to the expert team. This theoretical validity test considers construct validity and content validity. As for the questionnaire expert team, Dr. Mudjiran, M.Sc., Kons. as a guidance and counseling 
instrumentation expert, Dr. Nunu Burhanuddin, Lc, MA, and Dr. Wedra Aprison, M.Ag., as religious tolerance instrumentation expert.

After the instrument got the results of judgment and has been improved, the second stage, the instrument is tested on respondents. The try out was carried out on August 3, 2019 with 66 items of respondents in accordance with the characteristics of the study. The trial results are then analyzed to see whether the career aspirations instrument is valid or really can measure what is being measured. The validity is how far the instrument really measures what (object) is to be measured.[17] To determine the validity of the instrument of career aspirations in this study, Pearson Product Moment correlation techniques with formulas can be used:

$$
r x y=\frac{n\left(\sum x y\right)-\left(\sum x\right)\left(\sum y\right)}{\sqrt{\left(n \sum x^{2}\right)-\left(\sum x\right)^{2}\left(n\left(\sum y^{2}\right)-\left(\sum y\right)^{2}\right)}}
$$

Where:

rxy $\quad$ is the Pearson moment product correlation coefficient

$\Sigma \mathrm{n} \quad:$ is the number of observation pairs

$\Sigma \mathrm{x} \quad$ : is the number of observations of the variable $\mathrm{x}$

$\Sigma y \quad$ : is the number of observations of the variable $\mathrm{y}$

Test criteria, if $r$ arithmetic $>$ tables with a significance level of 0.05 then the measurement is valid and vice versa if $r$ arithmetic <the instrument table is invalid. In this case the researchers used SPSS (Statistical Product and Service Solution) for windows release 25.

The results of the trial show 66 items of valid religious tolerance instruments, so that 54 items of religious tolerance instruments can be used. Furthermore, the researchers conducted a reliability test with the aim of knowing to find the level of confidence or to determine the level of reliability of all measuring instruments (research instruments) in this study carried out using the Alpha formula.

$$
r_{11}=\left[\frac{k}{k-1}\right]\left[1-\frac{\sum \sigma^{2} b}{\sigma^{2} t}\right]
$$

where :

r11 = instrument reliability coefficient

$\mathrm{k}=$ number of questions

$\sum \sigma^{2} \mathrm{~b} \quad=$ number of item variants

$\sigma^{2}{ }_{\mathrm{t}} \quad=$ total variance between 0.80 to $1.0=$ very high

For testing criteria, if $r$ sum $>$ table, the tool is reliable. In this case the researchers used the help of the SPSS (Statistical Product and Service Solution) program for windows release 25). So we get the amount of Cronbach's Alpa religious tolerance instrument of 0.958 . So it is known that $r$ sum $=0.958>0.80$, it can be said that the instrument of religious tolerance is reliable.

In addition to the above types of instruments for the experimental group will also be given an assessment format consisting of "laiseg format" that will be given to each member after each group counseling service "laijapen format" will be given after several times of group 
counseling, while "laijapang format "That will be given to each member after the end of all group counseling service processes as specified or the contract ends.

After the research instrument is managed and tested for validity and reliability then the data is tabulated and data scoring is done. The alternative answers to this questionnaire consisted of always, often, sometimes, rarely and never, the researchers did with the intent of knowing the frequency of religious tolerance behavior or behavior experienced by students during interactions among fellow citizens of Xaverius Bukittinggi High School. As for the scoring guidelines, if the form of a positive statement is the score always (5), often (4), sometimes (3), rarely (2), and never (1), whereas if the negative statement form is the opposite of the positive.

Furthermore, calculated the number of data scores collected and grouped based on the categorization of the interval that has been determined and calculated frequency, as well as the percentage of response from respoden. The categorizing formula can be seen as follows: Interval $=$ Biggest Data-Smallest data $/$ Number of groups. Interval $=280-56=224 / 3=75$, 6667 , then it is considered 75 . After completing the data processing, the categorization criteria are known and are described as follows:

Table 2. Number of data scores

\begin{tabular}{llll}
\hline Category & Interval & F & \% \\
\hline Very Good & $\geq 227$ & 12 & 50 \\
Good & $183-226$ & 8 & 33.33 \\
Good enough & $139-182$ & 4 & 16.67 \\
Poor & $95-138$ & 0 & 0 \\
Very poor & $\leq 94$ & 0 & 0 \\
Total & & 24 & 100 \\
\hline
\end{tabular}

After the instrument (religious tolerance scale and laiseg questionnaire) was arranged then the researcher conducted pre-test to the experimental group and the control group. Furthermore, after the pretest was conducted, the researcher conducted an action (treatment) of group counseling activities with multicultural education-oriented cinema therapy techniques to the experimental group while the control group continued to do group counseling activities but without cinema therapy techniques with multicultural educational insight.

In this study each group counseling meeting goes through four stages, namely: the stage of formation, the stage of transition, the stage of activity and the stage of completion. The stages are as follows

\section{Formation Stage}

In the stage of forming the group leader prepares group members so that they are really ready to enter the group counseling implementation. The group leader (PK) in the formation stage makes various preparations

\section{Transition Phase}

At the transition stage the group leader explains again about the activities of group counseling. Question and answer about readiness and recognize the atmosphere of group members, asking if group members are ready for further activities. Followed by giving examples of topics that will be discussed in the activity.

\section{Activity Phase}


At this stage it is the core stage of group counseling activities. At this stage of the activity students are presented and guided to watch the cinema film with the theme specifically the development of religious tolerance for students with multicultural education perspectives. Before being watched the film was selected and selected in accordance with the development of the Ramaja. As for the films shown include films namely films; "Assalmualaikum Baijing" and Films of Police and Buskers ". The cinema therapy stages are carried out namely: a). Assessments stages, b). Implementation Phase, and c). Debriefing Stage,

\section{Termination Stage}

At the end of the stage is the stage of evaluation and follow-up of group activities, by explaining to the group members that the activities will be ended, then group members are asked to submit the benefits, benefits during participating in the activities, delivery in the form of impressions-messages for the implementation of further activities, then continued by praying as a sign the activity will end and close with singing the song "I know I am ready to do". The results achieved in this stage are a) the expression of group members' impressions about the implementation of the activity, b). The results of group activities that have been achieved, c). Formulation of further activity plans and d). Still felt the relationship between group members and a sense of togetherness, even though the activity was ended.

After taking group action activities with cinema therapy techniques with multicultural education insight, the researchers then collected data again using a questionnaire on religious tolerance and Laiseg scale.

Then after the data and tabulated, the data will be analyzed. Data analysis is one of the most important steps in research activities. With data analysis it will be able to prove a hypothesis and be interesting about the problem to be studied. Determination of data analysis techniques is done by looking at the characteristics of the data. Research data for increasing religious tolerance variables have the following characteristics: (1) pairing (pretest-posttest), (2) the sample is small (research subjects numbering 24 people), (3) using experimental / treatment research, (4) data in collected and presented ratio ratios and intervals.

Based on the characteristics of the data, the researcher conducts a data analysis using parametric techniques. Before conducting a comparison test, the researcher knows the homogeneity and normality test. After the data is homogeneous and normal then the $\mathrm{T}$ test is performed, so that it proves or answers the hypothesis.

Homogeneity test results that have been explained at the beginning of the determination of the sample data shows the results of the pretest with the statistics Based on Mean obtained significance on the self-esteem variable 0.948 far exceeding 0.05 . Thus the religious tolerance data is homogeneous. It is homogeneous and suitable for treatment. After the data is known to be homogeneous and treated then the researchers then conduct a normality test.

Normality test is performed to determine whether the distribution of a data obtained follows or approaches the normal distribution law of Gauss Nisfiannoor, 2009: 91). Calculation of normality test in this study using the Kolmogorov Smirnov test and assisted by the application of the SPSS 25 program. Criteria for data are normally distributed if the significance value $>0.05$ (Idris, 2000: 40). The results of data processing that were obtained normality test results significance value of $0.069>0.05$ experimental group, and the score of the control group significance value of $0.200>0.05$ then the data is nomal distribution.

After the data is declared to be normally distributed then the researcher conducts the $\mathrm{T}$ Paired Samles Test and the Independent Samples T Test. The test serves to test the research hypothesis. The hypotheses proposed in this study are:

a. There are differences in religious tolerance among experimental group students before and after participating in multicultural education group counseling activities. 
b. There are differences in the religious tolerance of control group students, before and after participating in group counseling activities with multicultural education.

c. There is a difference in the religious tolerance of the experimental group students with the control group before and after participating in group counselling activities with cinema therapy techniques with multicultural education.

the hypothesis testing decision criteria are as follows:

1. Test $\mathrm{T}$ Paired samples $=$ Reject $\mathrm{H} 0$ and accept $\mathrm{H} 1$ if probability (sig 2-tailed) $\leq$ alpha $(\alpha=$ 0.05 ) or $\mathrm{t}$ count $<\mathrm{t}$ table.

2. Independent $\mathrm{T}$-test samples $=>\mathrm{Accept} \mathrm{H} 0$ and reject $\mathrm{H1}$ if probability (sig 2-tailed) $\geq$ alpha $(\alpha=0.05)$ or $\mathrm{t}$ count $<\mathrm{t}$ table

\section{Result and Discussion}

\section{a. Difference in Religious Tolerance of Students Before and After Group counseling Activities with Experimental Group Cinema therapy Techniques}

From the results of the description of the data on the development of religious tolerance of the experimental group students above shows the score scores between before and after the implementation of group counseling activities with multicultural education-oriented cinema therapy techniques there are different sizable numbers and aimed at positive constructive development. This was proved quantitatively Asmyp probability scores. Sig. (2-tailed) is $0,000<0.05$, then $\mathrm{H} 0$ is rejected and $\mathrm{H} 1$ is accepted, meaning there is significant differences in the religious tolerance of the experimental group students before (pretest) and after (Posttest) group counseling activities with multicultural education-oriented cinema therapy techniques.

This condition shows that group counseling activities with cinema therapy techniques with multicultural education insight are effective to be applied and developed for students in schools. This reinforces the statements of Dermer and Hutchings "The process of using film as an intervention and describing it as an indirect approach process, which can be applied to deal with various problems. The problems in question include religious tolerance.[9] The effectiveness of cinema therapy helps problems proven also by Eysenck where after being given cinema therapy self-esteem increases.[18] Self-esteem in question is the ability of individuals to appreciate themselves when individuals are able to do something positive. Religious tolerance will be realized when individuals are able to do something positive for themselves.

In addition, the results of Arjoni and Gusril Basir's research strengthened the results of this study and explained that there were significant differences in the morals development of adolescents in the orphanage of Aisyiah Kamang Downstream in Kab. Agam.[19] Tolerance is the embodiment of character towards the community environment. From the results of Arjoni and Gusril basir's research explain among the factors that influence the development of adolescent morals through group counseling activities with effective cinema therapy techniques, among others, caused by the cinema therapy technique using films that indirectly can inspire and provide a moral model for the audience. Sharp, Smith, \& Cole explain that cinema therapy as a therapeutic technique involves careful selection and assignment of films so that clients watch with follow-up processing their experiences during the therapy session.[11] Films serve to educate clients, normalize and reframing problems, and broadening ideas. In addition to this, Rafiqah described the results of his research as delivering; "The inculcation of religious tolerance in religious education at SMK YPP 2 Selaman Yogyakarta 
through the methods used to read, lecture, discuss, question and answer and demonstrate with the approach used student center learning. Can help students form moral knowing or exemplary, so that tolerance is instilled to be able to respect others, give freedom of worship to other religions, provide equal opportunities to fellow believers, recognize the rights of everyone.

Paying attention to some of the results of research and some of these theories provide reinforcement and stability of effective cinema therapy techniques carried out for the development of religious tolerance of students at school.

\section{b. Difference in Religious Tolerance of Students Before and After Group counseling Activities with Control Group Cinema therapy Techniques}

From the results of the development of religious tolerance students control group score scores between before and after the implementation of group counseling activities without cinemateraphi techniques with multicultural education insight there are selish numbers, but not so aimed at rapid development. From the results of the calculation of the T Paired Samples test the Asmyp probability value. Sig. (2-tailed) is $0.923>0.05$, then $\mathrm{H} 0$ is accepted and $\mathrm{H} 1$ is rejected, meaning that there is no difference in the religious tolerance of the control group students before (pretest) and after (Posttest) group counseling activities without cinema therapy techniques with multicultural education insight.

The description of the results of the study shows that group counseling activities contribute to change to develop student religious tolerance, but the development carried out has not shown a significant contribution. Basically, group counseling activities have the potential to develop students' potential, as Achmad Juntika points out; "Group counseling is assistance to individuals carried out in group situations. Guidance groups can be in the form of delivery of information or group activities discussing issues of education, work, personal and social.[6] The purpose of group counseling specifically encourages the development of feelings, thoughts, perceptions, insights and attitudes that support the realization of more effective behaviors, namely enhancing students' verbal and non-verbal communication skills. According to Prayitno that the purpose of group counseling is as follows: Able to speak in front of people, Able to issue opinions, ideas, suggestions, responses, feelings and so on to many people, Learn to respect the opinions of others, Be responsible for the opinions expressed, Able to control self and restrain emotions (psychiatric turmoil that is negative), Can tolerate, Become familiar with each other, Discuss problems or general topics that are felt or become a common interest.[7]

Paying attention to research results and the theoretical basis of group counseling activities have a straight line when supported by techniques that seek to realize the development of religious tolerance such as cinema therapy techniques. Group counseling activities organized in the control group without using cinema therapy techniques have the potential to develop students' religious tolerance and will further develop when utilizing cinema therapy techniques.

\section{c. Factors That Influence Student's Religious Tolerance}

Based on table 4.11 above, the Asmyp probability value is known. Sig. (2-tailed) is 0.041> 0.05 , then $\mathrm{H} 0$ is rejected and $\mathrm{H} 1$ accepts it means that there is a difference in the religious tolerance of the experimental group students with the control group after (Posttest) group counseling activities with cinema therapy techniques with multicultural education insight. There are several factors that influence religious tolerance. Factors that influence the 
development of religious tolerance can be seen from internal factors (knowledge, interests, attitudes, skills and experience) and externally influenced by the environment and the mass media (Bahari, 2010).

It is noted from the results of the research that these two factors potentially influence the development of religious tolerance of Xaverius Bukittinggi high school students. Potentially Personally each Xaverius Bukittinggi high school student has a prominent academic background, it is known as to how the explanation from the Xaverius high school headmaster stated that students at the school generally came from students who had potential academic and non-academic potential, this was the reason support the quality of schools to achieve accreditation A.

The external environment of the school environment in the form of curriculum has the potential to influence the development of religious tolerance for Xaverius high school students. This is reinforced by the explanation of Ibrahim's statement states; to carry out a democratic education which is of course also tolerant, there are three basic requirements that must be fulfilled; First, the practice of education always emphasizes the principle of justice so that all students get a fair and equal education. Second, the learning process is kept away from the nature of bias and stereotypes. Third, the learning process leads to the development of students' awareness of themselves, respect for other cultures outside of themselves, and being able to work together amidst existing cultural differences.[20] The multicultural education environment contributes to the development of religious tolerance.

According to Banks, the implementation of multicultural education in the school environment can be seen from several indicators, including (1) educational policies that support diversity, (2) positive attitudes of education staff towards diversity of students, (3) transformational curriculum and action focused on the concept diversity, (4) monitoring of the multicultural education process by school supervisors. From the four indicators, it can be seen that the development of school culture and the learning process has a strategic role in the implementation of multicultural education which is in line with the development of religious tolerance.[21]

Tolerance is a basic element needed to foster mutual understanding and respect for differences, as well as Community become an entry point for the realization of an atmosphere of dialogue and harmony among religious believers in society. To avoid conflicts between religious believers, tolerance must become a collective awareness of all community groups, from the level of children, adolescents, adults, to parents, both students, employees, bureaucrats and students. More than that, the principles of tolerance must really work to regulate the life of the community effectively.[1]

\section{Conclusion}

After the experiments have been proven; there is a significant difference in the religious tolerance of experimental group students before and after group counseling activities with multicultural education-oriented cinema therapy techniques, there is no difference in the religious tolerance of control group students before and after group counseling activities without using cinema therapy techniques with multicultural education-oriented techniques, and there are significant differences in tolerance religious students in the experimental group with the control group after group counseling with cinema therapy techniques with multicultural education insight. 
The results of this study can be used as consideration for developing a counselling program for the development of religious tolerance in high schools.

\section{Acknowledgment}

Ministry of religion of the Republic of Indonesia who provides financial assistance to BOPTN IAIN Bukittinggi.

\section{References}

[1] A. Mas'ud, "Interview," 2010.

[2] S. Mokodenseho, "Toleransi Beragama Dan Pembelajaran Agama Islam: Harmoni Masyarakat Minoritas Muslim Manado," in Prosiding Seminar Nasional \&Temu Ilmiah Jaringan Peneliti IAI Darussalam Blokagung Banyuwangi., 2018.

[3] C. Pemungkas, “Toleransi Beragama dalam Praktek Sosial,” J. Epistime, vol. 02, no. 09, 2014.

[4] T. Suryana, "Konsep dan Aktualisasi Kerukunan Antar Umat Beragama," J. AtTa'lim, vol. 9, no. 2, 2011.

[5] R. Ibrahim, "Interview," 2013.

[6] A. Juntika, Bimbingan dan Konseling dalam Berbagai Latar Kehidupan. Bandung: PT. Refika Aditama, 2006.

[7] Prayitno, Jenis Layanan dan Kegiatan Pendukung Konseling. Padang: UNP Press, 2012.

[8] S. Amin, Pengantar Bimbingan dan Konseling. Banda Aceh: PENA, 2014.

[9] S. B. Dermer and J. . Hutchings, "Utilizing Movies In Family Therapy: Applications for Individuals, Couples, and Families," Am. J. Fam., 2000.

[10] L. E. Tyson, L. H. Foster, and C. M. Jones, "The Processof Cinematherapysa Therapeutic Intervention,” Alabama Couns. Assoc. J., vol. 26, no. 1, 2000.

[11] C. Sharp, J. . Smith, and A. Cole, "Cinematherapy: Metaphorically Promoting Therapeutic Change," Couns. Psychol. Q., vol. 15, no. 3, 2000.

[12] E. Marsick, "Film Selection in a Cinematherapy Intervention With Preadolescent Experiencing Parental Divorce," J. Creat. Ment. Heal., vol. 5, no. 5, 2010.

[13] H. A. R. Tilaar, Kekuasaan dan Pendidikan: Suatu Tinjauan dari Perspektif Kultural. Magelang: Indonesia Tera, 2003.

[14] Dwi Hanato Adi, "Interview," 2019.

[15] R. Hermawati and C. Paskarina, "Interview," 2016.

[16] Casram, "Membangun sikap toleransi beragama dalam masyarakat plural," J. Ilm. Agama dan Sos. Budaya, vol. 1, no. 2, 2016.

[17] S. Zakir and R. Hidayat, "Web-based learning model that can be implemented in learning settings without being limited by time, place and space," J. Theor. Appl. Inf. 
Technol., vol. 96, no. 23, pp. 7996-8005, 2018.

[18] H. F. Eysenck, The Effects of Psychotherapy: in Handbook of Abnormal Psychology. New York: Basic Book Inc., 1961.

[19] Arjoni and G. Basyir, "Pengembangan Akhlak Remaja Panti asuhan Aisyiah Kamang Hilir Kab. Agam,” Bukittinggi, 2018.

[20] R. Ibrahim, "Pendidikan Multikultural: Pengertian, Prinsip, dan Relevansinya dengan Tujuan Pendidikan Islam,” J. ADDIN, vol. 7, no. 1, 2013.

[21] A. M. Wibowo, "Indeks Pendidikan Multikultural di D.I. Yogyakarta," Yogyakarta, 2016. 